\title{
KAJIAN BIAYA PRODUKSI TERHADAP HARGA PENJUALAN \\ PADA PERUSAHAAN AGAR-AGAR KERTAS DI KECAMATAN PAMEUNGPEUK KABUPATEN GARUT
}

\author{
Oleh : \\ Ganjar Wiryati dan Sobariah \\ Dosen Jurusan Penyuluhan Perikanan Sekolah Tinggi Perikanan
}

\begin{abstract}
ABSTRAK
Harga jual harus menghasilkan laba yang mencukupi, seimbang, dengan investasi yang ditanamkan. Maka dari itu informasi biaya produk atau jasa sangat diperlukan dalam pengambilan keputusan penentuan harga jual, walaupun biaya bukan satu-stunya faktor penentu yang harus dipertimbangkan dalam penentuan harga jual. Industri agar-agar kertas di Kecamatan Pameungpeuk misalnya, saat ini masih ditangani secara tradisional, dengan permodalan yang relatif kecil dengan kapasitas produksi antara 16-20 kg agar-agar per hari, dengan tenaga kerja 5 orang, serta persaingan semakin besar. Berdasarkan hasil penelitian maka biaya produksi memberikan kontribusi terhadap harga jual sebesar $81,80 \%$ pada industri kecil tersebut, sedangkan sisanya $18,20 \%$ dipengaruhi oleh faktor variabel lain.
\end{abstract}

Kata Kunci : Biaya, Agar-agar Kertas, Harga.

\section{PENDAHULUAN}

\section{Latar Belakang}

Pembinaan terhadap Industri kecil dan menengah perlu dilakukan agar menjadi usaha yang efisien dan mampu berkembang, serta mampu meningkatkan pendapatan masyarakat, membuka lapangan kerja berperan dalam penyediaan barang dan jasa serta berbagai komponen, untuk memenuhi pasar dalam negeri dan luar negeri. Persaingan di berbagai usaha semakin besar terutama pada usaha yang memproduksi barang sejenis. Keadaan ini adalah ancaman bagi industri kecil yang harus segera di upayakan karena mempengaruhi kelangsungan hidup usahanya, mengingat penjualan merupakan sumber pendapatan utama bagi perusahaan. Dalam upaya mengatasi hal tersebut perusahaan dituntut untuk antisipasi terhadap segala kemungkinan yang terjadi pada persaingan. Salah satunya adalah menentukan harga jual.

Perolehan laba yang diinginkan secara maksimal umumnya merupakan tujuan utama dari suatu kegiatan produksi. Biaya produksi dan laba yang diinginkan akan berperan dalam mempertimbangkan terbentuknya harga jual. Salah satu faktor yang memiliki kepastian dalam menentukan harga jual adalah biaya produksi. Biaya produksi memberikan batas bawah terhadap harga jual yang ditentukan. Perusahaan akan mengalami kerugian apabila harga jual berada di bawah biaya produksi, 
kerugian yang timbul dalam jangka waktu tertentu akan mengakibatkan terhambatnya dalam pertumbuhan usaha. Maka perusahaan memerlukan informasi tentang biaya produk dalam pengambilan keputusan harga jual.

Pengaruh dari luar perusahaan menyangkut permintaan konsumen atas produk bisa elastis maupun inelastis kepada siapa produk di jual , permintaan konsumen juga faktorfaktor lain di luar perusahaan tidak mudah di tentukan, maka penentuan harga jual yang dilakukan menghadapi banyak ketidakpastian. Untuk itu perlu di ketahui sejauh mana kontribusi biaya produksi berpengaruh terhadap penentuan harga jual suatu produk pada industri pembuatan agar-agar kertas di kecamatan Pameungpeuk Kabupaten Garut.

Saat situasi normal pada dasarnya harga jual produk atau jasa harus menutupi biaya penuh yang bersangkutan dengan produk atau jasa serta menghasilkan laba yang di kehendaki. Biaya penuh merupakan total pengorbanan sumberdaya untuk memperoleh produk dan jasa, sehingga seluruh pengorbanan ini harus dapat ditutup oleh pendapatan yang di peroleh dari penjualan produk atau jasa. Harga jual juga harus menghasilkan laba yang mencukupi, seimbang dengan investasi yang ditanamkan. Maka dari itu informasi biaya produk atau jasa sangat diperlukan dalam pengambilan keputusan penentuan harga jual, walaupun biaya bukan satu-satunya faktor yang harus di pertimbangkan dalam penentuan harga jual.

Sasaran utama industri agar-
agar kertas rumput laut adalah
memperoleh laba. Dalam upaya
memperoleh laba tersebut mereka

mengeluarkan pengorbanan atau biaya yang tinggi, sehingga pengusaha harus berusaha keras dalam melaksanakan usahanya dengan tujuan untuk menutupi biaya-biaya yang dikeluarkan dengan harapan memperoleh hasil yang mendatangkan keuntungan yang tinggi.

Industri pembuatan agar-agar kertas di kecamatan Pameungpeuk saat ini masih ditangani secara tradisional, dengan permodalan yang relatif kecil, kapasitas produksi antara 16 - $20 \mathrm{~kg}$ agar-agar per hari, dengan tenaga kerja $4-5$ orang, juga karena persaingan. Untuk dapat mempertahankan usahanya, pengusahan dituntut memiliki kemampuan menghadapi persaingan guna memperoleh peluang pasar.

Dalam menentukan harga jual pembuat agar-agar belum memperhatikan faktor-faktor yang mempengaruhi harga jual produknya, perhitungan biaya belum dilakukan secara benar, ada biaya yang belum di perhitungkan dalam penghitungan biaya produksi, seperti biaya tenaga kerja pemilik atau keterkaitan keluarga dalam usaha. Selain itu perusahaan belum memperhitungkan biaya overhead pabrik, misalnya biaya reparasi mesin atau peralatan pabrik dan biaya pemeliharaan mesin. Sudah seharusnya perusahaan memperhatikan faktor-faktor yang mempengaruhi dalam penentuan harga jual produk untuk kelangsungan usahanya. Pada industri pembuatan agar-agar kertas ini belum memperhatikan faktor-faktor tersebut terutama biaya produksi. Dengan demikian ada ketidaksesuaian antara kondisi ideal dengan kenyataan di lapangan, sehingga kurang tepat 
dalam melakukan penentuan harga jual.

\section{Kerangka Pemikiran}

Setiap perusahaan tentu mempunyai maksud dan tujuan yang ingin dicapai. Dalam rangka pencapaian maksud dan tujuan tersebut perusahaan harus mempunyai strategi. Salah satunya yaitu penentuan harga jual. Penelitian ini hanya mengkaji satu faktor saja biaya produksi. Faktor biaya produksi sangat berperan dalam menentukan harga jual. Agar harga jual sesuai dengan yang diinginkan, maka harus memperhatikan biaya-biaya untuk memproduksi suatu produk, karena biaya akan memberikan informasi batas bawah terhadap harga jual yang akan ditentukan.
Dengan memperhatikan biaya produksi tersebut diharapkan akan tepat dalam penentuan harga jual. Hal ini menunjukkan suatu keterkaitan antara biaya produksi dan harga jual. Secara umum untuk membentuk harga jual suatu produk merupakan penjumlahan antara laba yang di inginkan dengan biaya produksi. Jadi jika Biaya produksi yang dikeluarkan pada suatu produk tinggi, maka laba yang diinginkan seharusnya disesuaikan dengan harga jual di pasaran dan sebaliknya jika menginginkan laba yang diinginkan tinggi maka produsen harus dapat menekan biaya produksi. Keterkaitan tersebut dapat di gambarkan dalam kerangka pikir sebagai berikut:

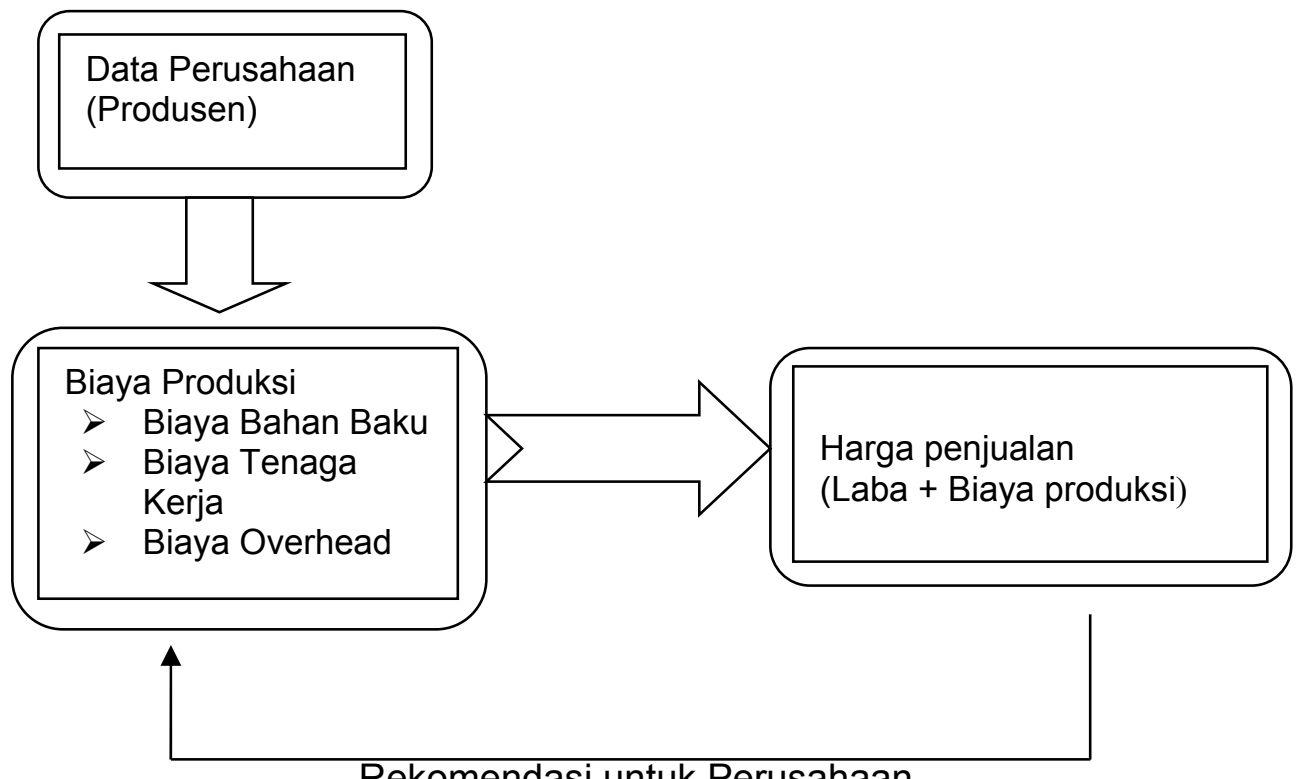

Gambar 1. Kerangka Pemikiran

\section{Metode Penelitian}

Penelitian di lakukan pada bulan Mei sampai dengan bulan Juni tahun 2010, bertempat di perusahaan agar-agar kertas Kecamatan Pameungpeuk, Kabupaten Garut.
Variabel di bedakan menjadi dua yaitu variabel bebas dan variabel terikat. Variabel bebas $(X)$ adalah variabel yang mempengaruhi. Variabel terikat (Y) adalah akibat (Arikunto, 2000). Adapun dalam penelitian ini sebagai 
variabel bebasnya yaitu biaya produksi $(X)$ sedangkan variabel terikat yaitu harga jual $(\mathrm{Y})$.

Pengambilan data di lakukan dengan cara observasi dan wawancara langsung dengan 3 pemilik industri agar-agar kertas, sehingga data di sajikan merupakan hasil rata-rata biaya yang di keluarkan oleh pemilik industri tersebut.

Model analisis data yang digunakan adalah analisis regresi sederhana, persamaan linear sederhana menunjukkan hubungan antara dua variabel, yaitu variabel $X$ sebagai variabel independen dan variabel $Y$ sebagai variabel dependen (Algifari, 2000). Regresi linear sederhana digunakan untuk mengetahui pengaruh biaya produksi terhadap harga jual. Model persamaan regresi yang digunakan dalam pengujian adalalah:

\section{a. Persamaan regresi Sederhana}

Regresi sederhana

$$
Y^{\prime}=a+b x
$$

Keterangan :

$Y^{\prime}=$ Subyek dalam variabel dependen yang diprediksikan

$\mathrm{a}=$ Harga $\mathrm{Y}$ bila $\mathrm{X}=0$ (harga konstan)

$\mathrm{b}=$ Angka Arah atau koefisien regresi, yang menunjukkan angka peningkatan ataupun penurunan variabel dependen yang didasarkan pada variabel independen.

Bila b $(+)$ maka naik, dan bila ( - ) maka terjadi penurunan.
$\mathrm{X}$ = Subyek pada variabel independen yang mempunyai nilai tertentu.

(Sugiyono, 2005).

Atau dengan menghitung a dan $b$ yaitu dengan rumus:

$$
\begin{aligned}
& a=\frac{\left(\sum Y_{1}\right)\left(\sum X_{1}{ }^{2}\right)-\left(\sum X_{1}\right)\left(\sum X_{1} Y_{1}\right)}{N \sum X^{2}{ }_{1}-\left(\sum X_{1}\right)^{2}} \\
& b=\frac{n \sum X_{1} Y_{1}-\left(\sum X_{1}\right)\left(\sum Y_{1}\right)}{n \sum X_{1}{ }^{2}-\left(\sum X_{1}\right)^{2}}
\end{aligned}
$$

\section{b.Uji hipotesis}

1). Uji t-statistik

Uji t digunakan untuk menguji koefisien regresi secara parsial dari variabel independennya. Nilai t hitung masing-masing kooefisien regresi dapat diketahui dari hasil perhitungan komputer. Untuk menentukan nilai $t$ statistik tabel di tentukan tingkat signifikasi $5 \%$ dengan $\mathrm{df}=(\mathrm{n}-\mathrm{k}-1)$ dimana $n$ adalah jumlah observasi dan $\mathrm{k}$ adalah jumlah variabel termasuk intersep dengan kriteria uji adalah : Jika $t$ hitung $>\mathrm{t}$ tabel, maka Ho ditolak

Jika t hitung $>\mathrm{t}$ tabel, maka $\mathrm{Ha}$ di terima

Hipotesisnya yaitu :

Ho $=$ ß $1=0 \quad$ $0 \quad=0$

tidak terdapat pengaruh yang signifika dari variabel independen $(X)$ terhadap variabel dependen $(\mathrm{Y})$

$$
\mathrm{Ho}=\text { ß \# } 0 \quad \text { ß \# } 0
$$

Artinya terdapat pengaruh yang signifikan dari variabel indefenden $(X)$ terhadap variabel dependen $(\mathrm{Y})$

2). Koefisien diterminasi

Untuk ukuran statistik yang dapat menggambarkan hubungan antara suatu variabel dengan variabel lain adalah koefisien determinasi dan koefisien korelasi. Koefisien determinasi di beri simbol (r2) dan 
koefisien korelasi diberi simbol $r$. Koefisien determinasi adalah salah satu nilai statistik yang dapat digunakan untuk mengetahui apakah ada hubungan pengaruh antara dua variabel.

Koefisien determinasi $\left(r^{2}\right)$ dari hasil regresi sederhana menunjukkan tingkat kejelasan yang dapat diberikan oleh model tersebut terhadap perubahan variabel dependen. Secara umum nilai $r^{2}$ terletak pada nilai 0 sampai dengan $1\left(0<r^{2}<1\right)$. Nilai koefisien determinasi menunjukkan persentase variasi nilai variabel dependen yang dapat di jelaskan oleh persamaan regresi yang di hasilkan.

\section{HASIL DAN PEMBAHASAN}

Pencapaian harga jual rata-rata setiap bulan pada tahun 2009 dari 4 industri agar-agar Kertas yang ada di Kecamatan Pameungpeuk Kabupaten Garut disajikan dalam Tabel 1 berikut:

Tabel 1. Harga Penjualan Agar-agar Kertas, Biaya Bahan Baku Agar-agar Kertas, Biaya Tenaga Kerja, Biaya Overhead Pabrik Tahun 2009

\begin{tabular}{|c|c|c|c|c|}
\hline Bulan & Harga Jual & BBB & BTK & BOP \\
\hline Januari & Rp. $59.076 .000,-$ & Rp. $22.770 .000,-$ & Rp. 7.500.000,- & $\begin{array}{ll}\text { Rp. } 1.500 .000,-\end{array}$ \\
\hline Febuari & Rp. 41.220.000,- & Rp. $21.274 .000,-$ & Rp. $7.000 .000,-$ & $850.000,-$ \\
\hline Maret & Rp. $45.665 .000,-$ & Rp. 23.478.000,- & Rp. 7.550.000,- & Rp. 2.000 .000$, \\
\hline April & Rp. $49.620 .000,-$ & Rp. 22.7744.000,-- & Rp. 7.500.000,- & $\begin{array}{ll}\text { Rp. } 1.250 .000,-\end{array}$ \\
\hline Mei & Rp. $45.665 .000,-$ & Rp. $22.864 .500,-$ & Rp. 7.750.000,- & Rp. $1.000 .000,-$ \\
\hline Juni & Rp. $44.250 .000,-$ & Rp. $23.384 .000,-$ & Rp. 7.500.000,- & $\overline{750.000,-}$ \\
\hline Juli & Rp. 45.665.000,- & Rp. 23.479.000,- & Rp. $7.750 .000,-$ & $500.000,-$ \\
\hline Agustus & Rp. $44.250 .000,-$ & Rp. $22.770 .000,-$ & Rp. $7.750 .000,-$ & Rp. $2.200 .000,-$ \\
\hline September & Rp. $55.831 .000,-$ & Rp. $23.479 .000,-$ & Rp. $7.500 .000,-$ & $850.000,-$ \\
\hline Oktober & Rp. $44.250 .000,-$ & Rp. $22.860 .000,-$ & Rp. $7.500 .000,-$ & $\overline{500.000,-}$ \\
\hline November & Rp. $44.250 .000,-$ & Rp. 23.384.000,- & Rp. $7.500 .000,-$ & $500.000,-$ \\
\hline Desember & Rp. $57.081 .250,-$ & Rp. 23.479.000,- & Rp. 7.500.000,- & $\begin{array}{ll}\text { Rp. } 1.500 .000,-\end{array}$ \\
\hline $\begin{array}{c}\text { Total Harga } \\
\text { Jual }\end{array}$ & Rp. 576.823.250,- & Rp. 275.995.500,- & Rp. 90.300.000,- & Rp. 13.400.000, \\
\hline
\end{tabular}

Ket: BBB = Biaya Bahan Baku

$\mathrm{BTK}=$ Biaya Tenaga Kerja

$\mathrm{BOP}=$ Biaya Operasional Pabrik

Secara keseluruhan persentase tingkat pengeluaran biaya produksi untuk tahun 2009 adalah sebagai berikut:

Tabel 2. Persentase Biaya Produksi Tahun 2009

\begin{tabular}{|c|r|r|}
\hline $\begin{array}{c}\text { Persentase Biaya Produksi } \\
\text { Tahun 2009 Jenis Biaya }\end{array}$ & Biaya & Persentase (\%) \\
\hline Biaya Bahan Baku & Rp. 275.995.500,- & 72,68 \\
\hline Biaya Tenaga Kerja & Rp. $90.300 .000,-$ & 23,81 \\
\hline Biaya Overhead Pabrik & Rp. $13.400 .000,-$ & 3,51 \\
\hline Total & Rp. 379.695.500,- & $\mathbf{1 0 0}$ \\
\hline
\end{tabular}




\section{Hasil Penelitian}

Sub bab ini merupakan hasil data industri Agar-agar Kertas di Kecamatan Pameungpeuk Kabupaten Garut yang meliputi biaya produksi dan harga jual pada tahun 2009. Hasil penelitian ini akan memaparkan hasil persamaan regresi sederhana.
Hasil Persamaan Regresi Sederhana

Hasil analisis regresi linier sederhana dengan menggunakan program SPSS release 16,0 pada penelitian ini diperoleh persamaan regresi yang menyatakan persamaan pengaruh biaya produksi $(X)$ terhadap harga jual $(Y)$

Tabel 3. Hasil Perhitungan Correlasi

\begin{tabular}{|l|l|r|r|}
\hline & & Harga Jual & Biaya Produksi \\
\hline Pearson Correlation & harga jual & 1.000 & .905 \\
\cline { 2 - 4 } & Biaya produksi & .905 & 1.000 \\
\hline \multirow{2}{*}{ Sig. (1-tailed) } & harga jual &. & .000 \\
\cline { 2 - 5 } & Biaya produksi & .000 &. \\
\hline $\mathrm{N}$ & harga jual & 12 & 12 \\
\cline { 2 - 4 } & Biaya produksi & 12 & 12 \\
\hline
\end{tabular}

Hasil Correlations Tabel $\mathbf{3}$ variabel $X$ dengan $Y$, nilai yang diperoleh sebesar 0,905 berarti terdapat hubungan yang sangat kuat antara variable biaya produksi dan variabel harga jual. Dan nilai signifikansinya (1-tailed) sebesar 0,000 kemudian di bandingkan dengan probabilitas 0,05 , ternyata nilai probabilitas 0,05 lebih besar dari nilai probabilitas sig (1-tailed) atau (0,05 > 0,000), maka Ho di tolak dan $\mathrm{Ha}$ di terima artinya signifikan.
Terbukti bahwa biaya produksi mempunyai hubungan secara signifikan terhadap harga jual.

Hasil dari uji koefisien (Tabel.4) diperoleh model regresi untuk menyatakan persamaan pengaruh biaya produksi $(X)$ terhadap harga jual ( $Y$ ) yaitu: $Y=-386471,987+0,905$. Dari persamaan regresi ini diperoleh $t_{\text {hitung }}$ sebesar 6.713. Sedangkan nilai $\mathrm{t}_{\text {tabel }}$ dari $\mathrm{df} 1=1 \mathrm{dan}$ df2=10 dengan taraf signifikan 0,01 adalah sebesar 3,169.

Tabel 4. Hasil uji Coefficients

\begin{tabular}{|c|c|c|c|c|c|c|c|c|c|}
\hline \multicolumn{10}{|c|}{ Coefficients $^{a}$} \\
\hline & \multirow{2}{*}{ Model } & \multicolumn{2}{|c|}{$\begin{array}{l}\text { Unstandardized } \\
\text { Coefficients }\end{array}$} & \multirow{2}{*}{$\begin{array}{c}\begin{array}{c}\text { Standardized } \\
\text { Coefficients }\end{array} \\
\text { Beta }\end{array}$} & \multirow{2}{*}{$\mathrm{t}$} & \multirow{2}{*}{ Sig. } & \multicolumn{3}{|c|}{ Correlations } \\
\hline & & B & $\begin{array}{l}\text { Std. } \\
\text { Error }\end{array}$ & & & & $\begin{array}{l}\text { Zero- } \\
\text { order }\end{array}$ & Partial & Part \\
\hline \multirow[t]{2}{*}{1} & (Constant) & -386471.987 & $7.258 \mathrm{E} 6$ & & -.053 & .959 & & & \\
\hline & \begin{tabular}{|l} 
Biaya \\
produksi
\end{tabular} & 1.421 & .212 & .905 & 6.713 & .000 & .905 & .905 & .905 \\
\hline & $\begin{array}{l}\text { Dependent } \\
\text { al }\end{array}$ & ole: harga & & & & & & & \\
\hline
\end{tabular}


Maka dapat diketahui bahwa $t_{\text {hitung }}=$ $6.713>\mathrm{t}_{\text {tabel }}=3,169$ yang berarti terdapat adanya pengaruh biaya produksi terhadap harga jual.

Koefisien regresi (Tabel.4) sebesar 0,905 menyatakan bahwa setiap penambahan (karena tanda + ) Rp. 1 rupiah biaya produksi akan meningkatkan harga penjualan Rp. 0,905 juta. Sebaliknya, jika biaya produksi turun sebesar Rp. 1 maka harga penjualan juga di prediksi mengalami penurunan sebesar Rp. 0,905. Jadi tanda + Hasil dari Model Summary (Tabel. 10), pada bagian ini di tampilkan nilai $R=0,905$ dan koefisien Determinan ( $R$ square) sebesar 0,818, hal ini menunjukkan bahwa harga penjualan $(\mathrm{Y})$ di pengaruhi sebesar $81,80 \%$ oleh biaya produksi $(X)$ sedangkan sisanya (100 $\%-81,8 \%=18,2 \%$ ) di jelaskan oleh sebab-sebab lain.

Regresi linear menyatakan arah hubungan yang searah, dimana kenaikan atau penurunan variable independen (X) akan mengakibatkan kenaikan/penurunan variable dependen $(Y)$.

Tabel 5. Hasil Uji Model Summary

Model Summary

\begin{tabular}{|c|c|c|c|c|c|c|c|c|c|}
\hline \multirow[b]{2}{*}{$\begin{array}{l}\text { Mod } \\
\text { el }\end{array}$} & \multirow[b]{2}{*}{$\mathrm{R}$} & \multirow[b]{2}{*}{$\begin{array}{c}\mathrm{R} \\
\text { Squar } \\
\mathrm{e}\end{array}$} & \multirow[b]{2}{*}{$\begin{array}{c}\text { Adjusted } \\
\mathrm{R} \\
\text { Square }\end{array}$} & \multirow[b]{2}{*}{$\begin{array}{c}\text { Std. Error } \\
\text { of the } \\
\text { Estimate }\end{array}$} & \multicolumn{5}{|c|}{ Change Statistics } \\
\hline & & & & & $\begin{array}{c}\text { R } \\
\text { Square } \\
\text { Change }\end{array}$ & $\begin{array}{c}\mathrm{F} \\
\text { Chang } \\
\mathrm{e}\end{array}$ & df1 & df2 & $\begin{array}{c}\text { Sig. } F \\
\text { Change }\end{array}$ \\
\hline 1 & $.905^{\mathrm{a}}$ & .818 & .800 & $\begin{array}{r}2.65314 \mathrm{E} \\
6\end{array}$ & .818 & 45.066 & 1 & 10 & .000 \\
\hline
\end{tabular}

a. Predictors: (Constant),

Biaya produksi

b. Dependent Variable:

harga jual

Tabel 6. Hasil Uji Anova

\begin{tabular}{|c|c|c|c|c|c|c|}
\hline \multicolumn{7}{|c|}{ ANOVA $^{b}$} \\
\hline \multicolumn{2}{|c|}{ Model } & $\begin{array}{l}\text { Sum of } \\
\text { Squares }\end{array}$ & Df & Mean Square & $\mathrm{F}$ & Sig. \\
\hline \multirow[t]{3}{*}{1} & Regression & $3.172 \mathrm{E} 14$ & 1 & $3.172 \mathrm{E} 14$ & 45.066 & $.000^{a}$ \\
\hline & Residual & 7.039E13 & 10 & 7.039E12 & & \\
\hline & Total & 3.876E14 & 11 & & & \\
\hline
\end{tabular}

a. Predictors: (Constant), Biaya produksi

b. Dependent Variable: harga jual 
Melihat Tabel Anova, Tabel 6 hasil nilai F 45,066 dengan tingkat probabilitas 0,001 , oleh karena probabilitas 0,001 jauh lebih kecil dari 0,05 , maka model regresi bisa di pakai untuk memprediksi penjualan. Untuk lebih jelasnya dapat dilihat pada Gambar 2.

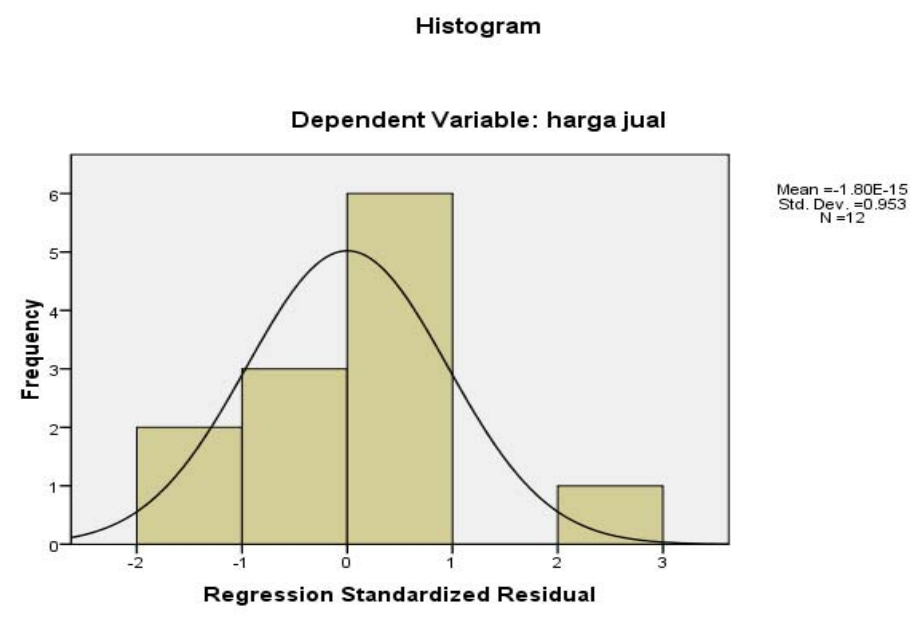

Gambar 2. Grafik Regresi Linear

Normal P-P Plot of Regression Standardized Residual

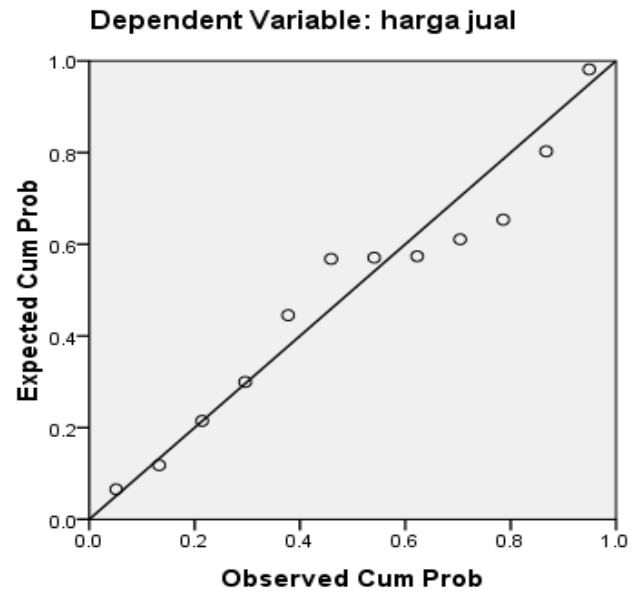

Gambar 3. Normal Probability Plot

Pada Gambar 3 menunjukkan penyebaran data-data yang ada pada variabel (menggambarkan regresi) karena titik-titik terletak mendekati atau sekitar garis lurus.

\section{Pembahasan}

Pada umumnya harga jual produk dan jasa ditentukan oleh perimbangan permintaan dan penawaran di pasar, sehingga biaya produksi dan laba bukan satu-satunya penentu harga jual. Selera konsumen, jumlah pesaing yang memasuki pasar, dan harga jual yang ditentukan pesaing, merupakan contoh faktorfaktor yang sulit untuk diramalkan, yang mempengaruhi pembentukan harga jual produk di pasar. Menurut Suryadi (2001) Penetapan harga jual 
yang tepat adalah merupakan salah satu faktor penting bagi perusahaan. Akan tidak berarti kalau sebuah perusahaan dapat memproduksi barang sangat baik namun tidak dapat menetapkan harga jual dengan tepat untuk barang produksinya. Pada pendekatan ini, harga jual ditentukan sebesar biaya total di tambah laba yang ditargetkan dan jumlah tersebut selanjutnya dengan unit produk atau jasa yang di anggarkan (Supriyono, 1989).

Dari data harga jual Tabel 1 diperoleh nilai rata-rata per bulan adalah sebesar Rp 48.068.604. maka dapat diketahui bahwa nilai harga jual pada bulan, Januari, April, September, dan Desember, diatas nilai rata-rata. Secara umum hal ini disebabkan karena penjualan atau pesanan produk Agar-agar kertas pada saat ini banyak dibutuhkan rumah tangga pada bulan ini terjadi peningkatan, dikarenakan pada bulan Januari dan April produk agar-agar kertas banyak konsumen yang memesan untuk keperluan tahun baru dan acara keluarga seperti acara pernikahan, sedangkan bulan September, dan Desember bertepatan dengan Menjelang perayaan Idul fitri dan Natal Sehingga penjualan juga meningkat.

Untuk harga jual Produk dibawah rata-rata perbulan di capai pada bulan Februari, Maret, Mei, Juni, Juli, Agustus, dan Nopember. Karena pada bulan ini tidak banyak konsumen yang membutuhkan Produk agar-agar Kertas, sehingga pesananpun menurun.

Tabel, 2,3, dan 4 menunjukkan data biaya yang di keluarkan oleh perusahaan dalam tahun 2009. Diketahui perusahaan mengeluarkan biaya yang terdiri dari biaya Bahan
Baku, Biaya Tenaga Kerja Dan Biaya Overhead Pabrik. Menurut Mulyadi (1999), Biaya produksi merupakan biaya yang terjadi untuk mengolah bahan baku menjadi produksi jadi yang siap untuk di jual, misalnya biaya bahan baku, biaya bahan penolong, biaya gaji karyawan dan lain-lain.

\section{Pengaruh Biaya Produksi terhadap Harga Jual}

Hasil penelitian mengenai biaya produksi tahun 2009 pada industri Produk agar-agar kertas terdiri dari tiga macam yaitu biaya bahan baku, biaya tenaga kerja dan biaya overhead pabrik. Pengaruh biaya produksi terhadap harga jual ini sebesar $81,80 \%$. Sedangkan sisanya sebesar $18,2 \%$ di pengaruhi sebab-sebab lain. Biaya merupakan faktor yang menentukan harga minimal yang harus di tetapkan agar perusahaan tidak megalami kerugian. Oleh karena itu, setiap perusahaan pasti menaruh perhatian pada aspek struktur biaya (Tetap dan variabel), serta jenis-jenis biaya lainnya. (Fandy Tjiptono, 1997). Hasil Correlations (Tabel. 3) variabel $X$ dengan $Y$, nilai yang diperoleh sebesar 0,905 berarti terdapat hubungan yang sangat kuat antara variable biaya produksi dan variabel harga jual. Dan nilai signifikansinya (1-tailed) sebesar 0,000 kemudian di bandingkan dengan probabilitas 0,05 , ternyata nilai probabilitas 0,05 lebih besar dari nilai probabilitas sig (1-tailed) atau (0,05 > 0,000), maka $\mathrm{Ho}$ di tolak dan $\mathrm{Ha}$ di terima artinya signifikan. Terbukti bahwa biaya produksi mempunyai hubungan secara signifikan terhadap harga jual.

Hal ini sudah sesuai dengan pendapat Mulyadi (1999), bahwa biaya 
mempunyai kepastian yang relatif tinggi dalam penentuan harga jual. Dalam penelitian ini diperoleh pengaruh yang sangat besar sekali, hal ini disebabkan karena penjualan produk berupa pesanan dengan penghitungan biaya variabel. Jadi biaya yang dikeluarkan akan berubah sebanding dengan kegiatan volume produksi.

Dari data biaya produksi tahun 2009 Tabel 1 diperoleh Nilai rata-rata biaya produksi perbulan adalah sebesar Rp 22.999.625. untuk pengeluaran biaya produksi di bawah rata-rata terjadi pada bulan Januari, Februari, April, Mei, Agustus dan Oktober, . Sedangkan untuk pengeluaran biaya produksi yang diatas rata-rata terjadi pada bulan Maret, Juni, Juli, September, Nopember dan Desember. Bila di lihat dari data harga jual dan biaya produksi, terdapat perbedaan dimana pada bulan-bulan tertentu keadaan harga produksi berada di bawah ratarata, akan tetapi harga jual berada di bawah rata-rata tidak pada bulan yang sama. Dengan keadaan harga jual di bawah rata-rata. Untuk harga bahan baku Agar-agar rumput laut relative tidak mengalami kenaikkan, harga relative stabil , untuk jenis Rumput Laut Jerum merah per kilogram Rp. 12.000,- Rumput Laut Cotonii per kilogram, Rp. 9.000,- Rumput Laut Spinosum per kilogram Rp. 6.000,--

Untuk biaya tenaga kerja pada industri pembuatan agar-agar kertas ini ada 2 macam yaitu tenaga kerja yang dibayar secara harian dan tenaga kerja borongan. biaya tenaga kerja pemilik atau anggota keluarga tidak dimasukkan dalam biaya tenaga kerja, padahal pemilik perusahaan atau anggota keluarganya juga ikut serta dalam kegiatan produksi jadi seharusnya ikut dimasukkan dalam biaya tenaga kerja. biaya tenaga kerja yang berhubungan langsung dengan proses produksi. Misalnya (gaji karyawan pabrik, upah mandor pabrik dan gaji manajer pabrik).(Fandi Tjiptono 1997).

Biaya overhead pabrik pada industri Agar-agar kertas ini adalah biaya yang dikeluarkan untuk pembelian Kayu Bakar, ada juga yang untuk membayar listrik. Dalam penghitungan biaya overhead pabrik pada industri Agar-agar ini juga kurang diperhitungkan dengan benar karena banyak unsur-unsur yang tidak dimasukkan dalam penghitungan biaya overhead pabrik, seperti biaya penyusutan peralatan mesin, biaya reparasi dan pemeliharaan mesin atau peralatan lainnya.

Secara keseluruhan persentase tingkat pengeluaran biaya produksi untuk tahun 2009 adalah seperti yang di tampilkan pada Tabel 2. Tabel tersebut menunjukkan bahwa biaya produksi yang terendah pada biaya overhead pabrik yaitu sebesar $3,51 \%$, untuk biaya tenaga kerja sebesar $23,81 \%$, sedangkan biaya produksi tertingginya untuk biaya bahan baku yaitu sebesar $72,68 \%$. Dengan melihat hal tersebut jelas bahwa penghitungan biaya produksi tidak diperhitungkan dengan benar, terutama dalam penghitungan biaya tenaga kerja dan biaya overhead pabrik.

\section{KESIMPULAN DAN SARAN}

\section{Kesimpulan}

1. Berdasarkan dari hasil penelitian, maka dapat di ambil kesimpulkan bahwa biaya produksi ( biaya bahan baku, biaya tenaga kerja 
dan biaya overhead pabrik), memberikan kontribusi terhadap harga jual sebesar $81,80 \%$ pada industri kecil pembuatan Agaragar Kertas di Kecamatan Pameungpeuk Kabupaten Garut, sedangkan sisanya sebesar $18,2 \%$ dipengaruhi oleh variabel lain.

2. Hasil Uji Correlation menunjukkan bahwa terdapat pengaruh yang signifikan biaya produksi yang di keluarkan terhadap penetapan harga jual, dengan nilai sig (1tailed) 0,000. Dengan tingkat probabilitas 0,05 , yakni tingkat kepercayaan $95 \%$.

3. Hasil dari uji koefisien diperoleh model regresi untuk menyatakan persamaan pengaruh biaya produksi $(X)$ terhadap harga jual $(\mathrm{Y})$ yaitu: $\mathrm{Y}=\mathbf{- 3 8 6 4 7 1 , 9 8 7 + 0 , 9 0 5}$. Dari persamaan regresi ini diperoleh $t_{\text {hitung }}$ sebesar 6.713. Sedangkan nilai $t_{\text {tabel }}$ dari $d f 1=1 d a n$ df2=10 dengan taraf signifikan 0,01 adalah sebesar 3,169.

Maka dapat diketahui bahwa $\mathrm{t}_{\text {hitung }}$ $=6.713>\mathrm{t}_{\text {tabel }}=3,169$ yang berarti terdapat adanya pengaruh biaya produksi terhadap harga jual.

\section{Saran}

Sebagai sumbang saran yang dapat di berikan dari hasil penelitian ini adalah sebagai berikut : Biaya produksi sebaiknya harus diperhitungkan dengan terperinci dalam satu rangkaian proses produksi tanpa kecuali karena biaya memberi sumbangan yang besar dalam penentuan harga jual. Terutama dalam penghitungan biaya tenaga kerja dan biaya overhead pabrik harus dipertimbangkan dengan cermat. Dan

biaya-biaya lainnya yang berhubungan dengan kegiatan produksi sebaiknya dimasukkan dalam biaya produksi.

\section{DAFTAR PUSTAKA}

Arikunto, Suharsimi, 1998. Prosedur Penelitian Suatu Pendekatan Praktik.

Rineka Cipta: Jakarta

Mulyadi. 2000. Akuntansi Biaya. Yogyakarta :Aditya Media

Supriyono. RA. 1999. Akuntansi Biaya : Yogyakarta : BPEE

Soegiono, 2005.Statistik Dalam Penelitian, Penerbit CV. Alfabeta Bandung

Sriyadi,2001. Pengantar Ekonomi Perusahaan Modern : Ikip Semarang

Tjiptono, Fandi. 1997. Strategi Pemasaran. Yogyakarta : Andi Yogyakarta 